Duct System Flammability and Air Sealing Fire Separation Assemblies in the International Residential Code
A. Rudd, ABT Systems, LLC
D. Prahl, IBACOS, Inc. 


\begin{abstract}
NOTICE
This report was prepared as an account of work sponsored by an agency of the United States government. Neither the United States government nor any agency thereof, nor any of their employees, subcontractors, or affiliated partners makes any warranty, express or implied, or assumes any legal liability or responsibility for the accuracy, completeness, or usefulness of any information, apparatus, product, or process disclosed, or represents that its use would not infringe privately owned rights. Reference herein to any specific commercial product, process, or service by trade name, trademark, manufacturer, or otherwise does not necessarily constitute or imply its endorsement, recommendation, or favoring by the United States government or any agency thereof. The views and opinions of authors expressed herein do not necessarily state or reflect those of the United States government or any agency thereof.
\end{abstract}

Available electronically at www.osti.gov/bridge

Available for a processing fee to U.S. Department of Energy and its contractors, in paper, from:

U.S. Department of Energy

Office of Scientific and Technical Information

P.O. Box 62

Oak Ridge, TN 37831-0062

phone: 865.576 .8401

fax: 865.576.5728

email: mailto:reports@adonis.osti.gov

Available for sale to the public, in paper, from:

U.S. Department of Commerce

National Technical Information Service

5285 Port Royal Road

Springfield, VA 22161

phone: 800.553 .6847

fax: 703.605.6900

email: orders@ntis.fedworld.gov

online ordering: www.ntis.gov/ordering.htm 


\title{
Duct System Flammability and Air Sealing Fire Separation Assemblies in the International Residential Code
}

\author{
Prepared for: \\ The National Renewable Energy Laboratory \\ On behalf of the U.S. Department of Energy's Building America Program \\ Office of Energy Efficiency and Renewable Energy \\ 15013 Denver West Parkway \\ Golden, CO 80401 \\ NREL Contract No. DE-AC36-08GO28308 \\ Prepared by: \\ A. Rudd \\ ABT Systems, LLC \\ 726 E. Maple Street \\ Annville, PA 17003 \\ D. Prahl \\ IBACOS, Inc. \\ 2214 Liberty Avenue \\ Pittsburgh, Pennsylvania 15222 \\ NREL Technical Monitor: Stacey Rothgeb \\ Prepared under Subcontract No. KNDJ-0-40341-04
}

December 2014 
The work presented in this report does not represent performance of any product relative to regulated minimum efficiency requirements.

The laboratory and/or field sites used for this work are not certified rating test facilities. The conditions and methods under which products were characterized for this work differ from standard rating conditions, as described.

Because the methods and conditions differ, the reported results are not comparable to rated product performance and should only be used to estimate performance under the measured conditions. 


\section{Contents}

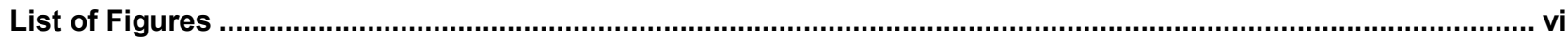

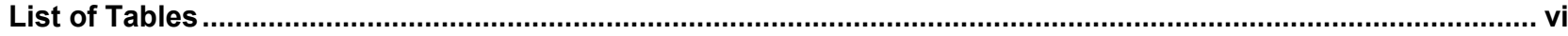

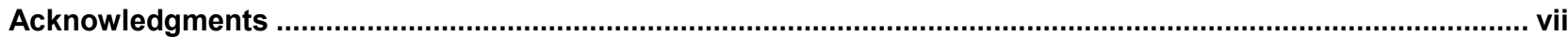

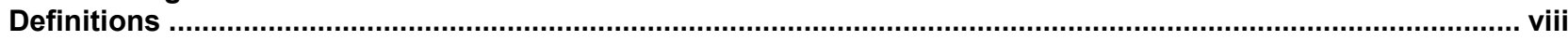

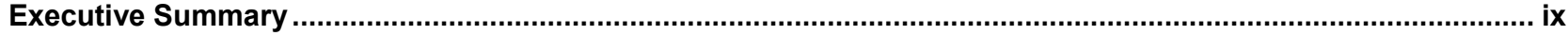

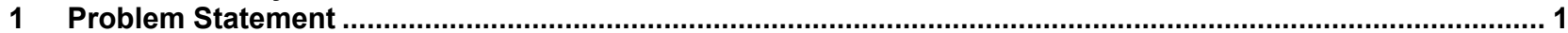

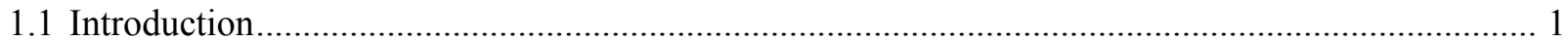

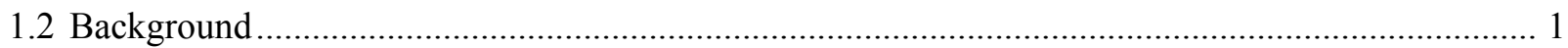

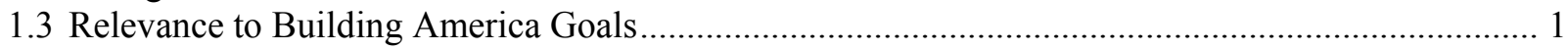

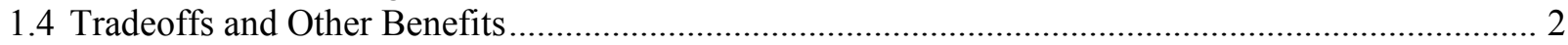

2 Guidance Template for Use in Discussions With Building Officials ........................................................ 3

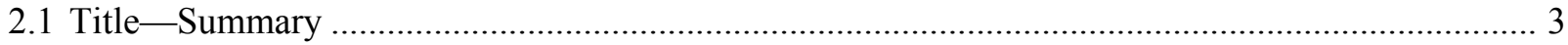

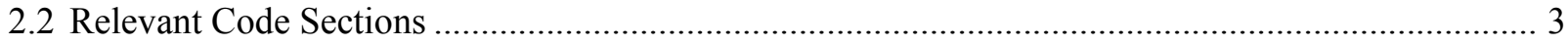

2.3 Other Citations

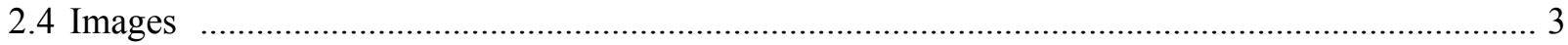

2.5 Discussion of Conflict and Underlying Building Performance Criteria ...................................... 3

2.5.1 Building Safety for Occupants in the Event of a Fire .................................................... 3

2.5.2 Building Safety for Firefighters and Emergency Responders .......................................... 3

2.6 Strategies to Discuss with Code Officials to Meet the Intent of the International Residential Code . 3

3 Completed Template—Nontraditional Duct System Materials .................................................................. 4

3.1 Nontraditional Duct Materials—Summary …......................................................................... 4

3.2 Relevant International Residential Code Sections ............................................................... 4

3.2.1 International Residential Code Section R101 …........................................................... 4

3.2.2 International Residential Code Section R104 …......................................................... 4

3.2.3 International Residential Code Section R202 ….................................................... 4

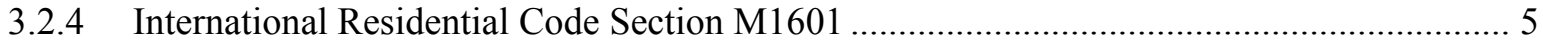

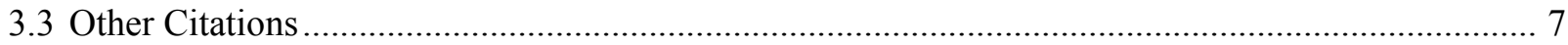

3.3.1 UL 181 Factory-Made Air Ducts and Air Connectors [UL 181 (2013)] .......................... 7

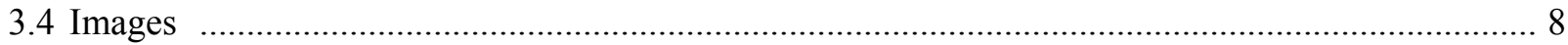

3.5 Discussion of Conflict and Underlying Building Performance Criteria ..................................... 8

3.5.1 Building Flammability and Safety for Occupants in the Event of a Fire........................... 8

3.5.2 Building Safety for Firefighters and Emergency Responders .......................................... 9

3.6 Strategies to Discuss with Code Officials to Meet the Intent of the International Residential Code 10

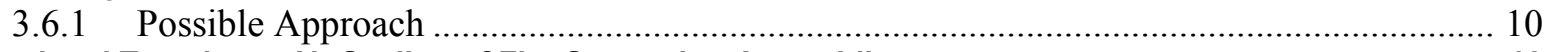

4 Completed Template_Air Sealing of Fire Separation Assemblies ......................................................... 12

4.1 Air Sealing of Fire Separation Assemblies - Summary …....................................................... 12

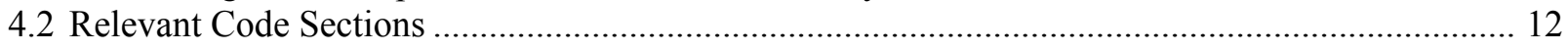

4.2.1 International Residential Code ............................................................................. 12

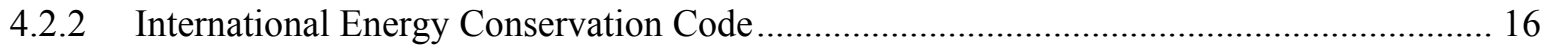

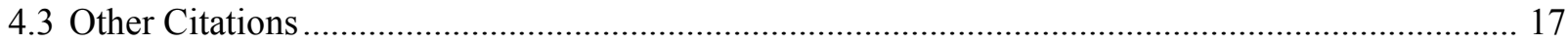

4.3.1 ASTM E-119-12a Standard Test Methods for Fire Tests of Building Construction and

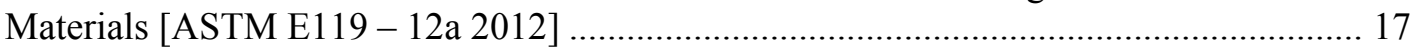

4.3.2 ASTM E136 - 12 Standard Test Method for Behavior of Materials in a Vertical Tube

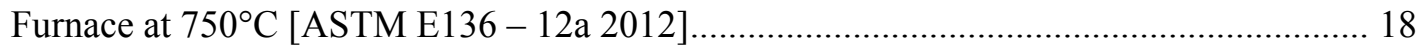

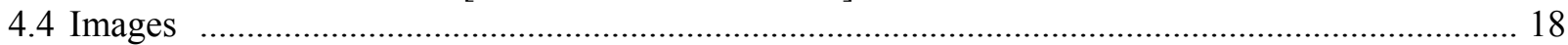

4.5 Discussion of Conflict and Underlying Building Performance Criteria ...................................... 19

4.5.1 Building Safety for Occupants in the Event of a Fire .................................................... 19

4.5.2 Building Safety for Firefighters and Emergency Responders ....................................... 20

4.6 Strategies to Discuss with Code Officials to Meet the Intent of the International Residential Code 20 


\section{List of Figures}

Figure 1. Fire separation walls (yellow or green gypsum shaft wall) in multifamily housing.

Figure 2. Examples of gaps where approved air sealing strategy is needed at the perimeter of fire separation walls

Unless otherwise noted, all figures and photos were created by IBACOS.

\section{List of Tables}

Table 1. Summary of Key Code Issues Related to Duct System Flammability and Smoke Developed..

Table 2. Fire Separation and Air Sealing Issues. . .7

Unless otherwise noted, all tables were created by IBACOS. 


\section{Acknowledgments}

The authors gratefully acknowledge the International Code Council for granting permission to reprint the following code sections in this report:

Section R101.3, R104.1, R202, M1601.1, M1601.1.1, M1601.1.2, M1601.2, M1601.3, M1601.4, M1604.4.6, R302.1, R302.2, R302.2.1, R302.2.4, R302.4, R302.4.1, R302.4.1.1, R302.4.1.2, R302.4.2, R302.11, R302.11.1, R302.11.1.1, R302.11.1.2, R302.11.1.3, R302.11.2, N1102.4, N1102.4.1, N1102.4.1.1, and N1102.4.1.2. Excerpted from the 2012 International Residential Code, copyright 2011. Washington, DC: International Code Council.

Sections R402.4, R402.4.1, R402.4.1.1, and R402.4.1.2. Excerpted from the 2012 International Energy Conservation Code, copyright 2011. Washington, DC: International Code Council.

Reproduced with permission. All rights reserved. www.ICCSAFE.org. 


\section{Definitions}

$\begin{array}{ll}\text { ACH } & \text { Air changes per hour } \\ \text { IBC } & \text { International Building Code } \\ \text { ICC } & \text { International Code Council } \\ \text { IECC } & \text { International Energy Conservation Code } \\ \text { IMC } & \text { International Mechanical Code } \\ \text { IRC } & \text { International Residential Code } \\ \text { NBFU } & \text { National Board of Fire Underwriters } \\ \text { UL } & \text { Underwriters Laboratories, Inc. }\end{array}$




\section{Executive Summary}

IBACOS identified two barriers that limit the ability of builders to explore opportunities for higher levels of energy efficiency in housing:

- The use of duct system materials that inherently achieve airtightness and are appropriately sized for low-load houses

- The ability to air seal fire separation assemblies.

These issues fall into a gray area of the codes.

A particular code section may have a requirement that leads to compliance problems in other code sections. Because a code official will need to decide on allowable practices to achieve all code sections, IBACOS developed a template to provide guidance for builders when discussing these problem areas so the builders can arrive at a mutually agreeable solution with their code officials. Anyone can use this template to create a logical framework for discussion when these types of conflicts are identified.

This report presents issues, relevant code sections, and points of discussions to have with a code official to develop a locally approved course of action related to the following:

- The use of duct system materials that inherently achieve airtightness and are right-sized for low-load houses

- The ability to air seal fire separation assemblies. 


\section{Problem Statement}

\subsection{Introduction}

IBACOS identified two barriers that limit the ability of builders to explore opportunities for higher levels of energy efficiency in housing:

- The use of duct system materials that inherently achieve airtightness and are right-sized for low-load houses

- The ability to air seal fire separation assemblies.

This report presents issues, relevant code sections, and discussion points to have with a code official to develop a locally approved course of action.

The use of small-diameter (2- to 4-in.) ducts made of common, nonmetallic materials that are "technically" allowed under the 2012 International Residential Code (IRC) (IRC 2012) Section M1601.1.1(6) needs to be supported. However, these are often rejected at the local jurisdiction level because the language in the IRC and other International Code Council (ICC) codes is often nonspecific, unclear, or incoherent. Over the long term, this problem requires engaging with the relevant ICC committees and industry stakeholders to clarify the overall performance intent of this code section and to revise or clarify documentation to remove barriers to the use of common, nonmetallic duct materials.

Relevant stakeholders also need to be engaged to develop a reasonable approach for the use of air sealing materials (e.g., caulks and one-part polyurethane foams) in fire separation assemblies. Sealants that have been approved for use within a dwelling unit to seal wire or pipe penetrations are not technically allowed to be used for sealing a nearby joint in the wall framing. Resolution of this kind of code difficulty will impact development of a longer-term strategy on least-cost solutions for ASTM E119 tested fire-rated assemblies (ASTM E119 - 12a 2012).

\subsection{Background}

This research was designed to provide guidance to builders, with strategies to discuss the ways to meet code requirements, such as whole-house airtightness and appropriate duct sizing, that conflict with language in the following codes:

- 2012 IRC Sections R302.2 and R302.11 (fire separation assemblies)

- 2012 IRC Section M1601.1.1 (IRC 2012)

- International Mechanical Code (IMC) (IMC 2012) Chapter 6 Duct Systems in Low-Rise Residential Buildings (International Building Code [IBC], Residential Group R3, Section 310 [IBC 2012]) (duct materials for small-diameter ducts).

\subsection{Relevance to Building America Goals}

Overall, the goal of the U.S. Department of Energy Building America program is to "reduce home energy use by 30-50\% (compared to 2009 energy codes for new homes and pre-retrofit energy use for existing homes)." To this end, IBACOS conducts research to "develop market- 
ready energy solutions that improve efficiency of new and existing homes in each U.S. climate zone, while increasing comfort, safety, and durability."1

This project could help achieve the Building America program goals of reducing home energy use in all U.S. climates zones, particularly in climate zones 1 to 5, where small nonmetallic duct systems (e.g., plastic or hybrid materials) could be used with available heat pump systems with variable capacity and variable airflow in low-load homes.

This project also could help achieve the Building America program goals of reducing home energy use in all U.S. climates zones where techniques are needed for creating airtight fire separation walls in multifamily housing to meet (at a minimum) the airtightness requirements in the 2012 IRC and the 2012 International Energy Conservation Code (IECC) (IECC 2012). Builders have stated that it is difficult to meet building enclosure airtightness targets in multifamily construction because the code requirements relative to approved sealant material for fire separation walls are unclear and inconsistent. Efforts to make these code provisions clear, consistent, and reasonable would facilitate faster approval of higher performing, air-sealed fire separation walls.

Work documented in this report highlights the code issues and provides builders with ways to discuss how to achieve all code provisions in projects that seek to meet U.S. Department of Energy Zero Energy Ready Home, 2012 IRC, or 2012 IECC requirements. Future work may include revisions to the code language or retesting assemblies that include air sealing materials.

\subsection{Tradeoffs and Other Benefits}

Better air sealing of fire separation walls will achieve the following:

- Improve space conditioning energy efficiency

- Improve fire resistance by limiting air movement (IRC 2012, p. 15, definition of "Fireblocking")

- Improve sound isolation

- Reduce odor transfer from unit to unit (Bohac et al. 2011).

\footnotetext{
${ }^{1}$ www1.eere.energy.gov/buildings/building_america/program_goals.html.
} 


\section{Guidance Template for Use in Discussions With Building Officials}

The issues identified by IBACOS fall into a gray area of the codes. A particular code section may have a requirement that leads to compliance problems in other code sections. Because a code official will need to decide on allowable practices to achieve all sections of the code, IBACOS developed the following template to provide guidance for builders when discussing these problem areas so the builders can arrive at a mutually agreeable solution with their code officials. Anyone can use this template to create a logical framework for discussion when these types of conflicts are identified.

\subsection{Title-Summary}

Title of the summary and short overview of the issue.

\subsection{Relevant Code Sections}

Citations for the ICC publications.

\subsection{Other Citations}

Other relevant citations, such as test methods or standards.

\subsection{Images}

Images that help visualize the issue or problem being addressed.

\subsection{Discussion of Conflict and Underlying Building Performance Criteria 2.5.1 Building Safety for Occupants in the Event of a Fire}

How does the particular issue relate to the safety of the occupants in the building in the event of a fire?

\subsubsection{Building Safety for Firefighters and Emergency Responders}

How does the particular issue relate to the safety of firefighters and emergency responders in the building in the event of a fire?

\subsection{Strategies to Discuss with Code Officials to Meet the Intent of the International Residential Code}

Using a hierarchy of safety and a data-based risk analysis, provide the building official with information supporting the proposed solution. 


\section{Completed Template-Nontraditional Duct System Materials}

In this section, IBACOS has completed a template for the use of nontraditional duct materials in one- and two-family buildings.

\subsection{Nontraditional Duct Materials-Summary}

The IRC codes pertaining to residential duct systems cite a variety of properties and performance criteria; however, none is internally consistent with the others. For example, factory-made ducts are required to have a flame spread no greater than 25 in Table M1601.1.1(1) of the 2012 IRC, but duct systems can have a flame spread of no less than 200 according to Section M1601.1.1(6). The following sections document these issues and discussion points.

\subsection{Relevant International Residential Code Sections}

All code citations are taken directly from the 2012 IRC (IRC 2012), reproduced here with permission from the ICC as detailed in the Acknowledgments section of this report. (All rights reserved. www.ICCSAFE.org.) Relevant sections are highlighted in yellow. Table 1 follows the code citations and lists a summary of specific code issues.

\subsubsection{International Residential Code Section R101}

R101.3 Intent. The purpose of this code is to establish minimum requirements to safeguard the public safety, health and general welfare through affordability, structural strength, means of egress facilities, stability, sanitation, light and ventilation, energy conservation and safety to life and property from fire and other hazards attributed to the built environment and to provide safety to firefighters and emergency responders during emergency operations.

\subsubsection{International Residential Code Section R104}

R104.1 General. The building official is hereby authorized and directed to enforce the provisions of this code. The building official shall have the authority to render interpretations of this code and to adopt policies and procedures in order to clarify the application of its provisions. Such interpretations, policies and procedures shall be in conformance with the intent and purpose of this code. Such policies and procedures shall not have the effect of waiving requirements specifically provided for in this code.

\subsubsection{International Residential Code Section R202}

APPLIANCE. A device or apparatus that is manufactured and designed to utilize energy and for which this code provides specific requirements. [IRC 2012, p. 11]

APPROVED. Acceptable to the building official. [IRC 2012, p. 11]

DUCT SYSTEM. A continuous passageway for the transmission of air which, in addition to ducts, includes duct fittings, dampers, plenums, fans and accessory air-handling equipment and appliances. [IRC 2012, p. 14]

EQUIPMENT. All piping, ducts, vents, control devices and other components of systems other than appliances that are permanently installed and integrated to provide control of environmental

\footnotetext{
${ }^{2}$ Also see IRC Section R104.11 for specific language related to alternative material, design, and methods of construction and equipment.
} 
conditions for buildings. This definition shall also include other systems specifically regulated in this code. [IRC 2012, p. 15]

\subsubsection{International Residential Code Section M1601}

M1601.1 Duct design. Duct systems serving heating, cooling and ventilation equipment shall be installed in accordance with the provisions of this section and ACCA Manual D or other approved methods.

M1601.1.1 Above-ground duct systems. Above-ground duct systems shall conform to the following:

1. Equipment connected to duct systems shall be designed to limit discharge air temperature to a maximum of $250^{\circ} \mathrm{F}\left(121^{\circ} \mathrm{C}\right)$.

2. Factory-made air ducts shall be constructed of Class 0 or Class 1 materials as designated in Table M1601.1.1(1).

TABLE M1601.1.1(1)

CLASSIFICATION OF FACTORY-MADE AIR DUCTS

\begin{tabular}{|c|c|}
\hline DUCT CLASS & MAXIMUM FLAME SPREAD INDEX \\
\hline 0 & 0 \\
\hline 1 & 25 \\
\hline
\end{tabular}

3. Fibrous duct construction shall conform to the SMACNA Fibrous Glass Duct Construction Standard or NAIMA Fibrous Glass Duct Construction Standards.

4. Minimum thickness of metal duct material shall be as listed in Table M1601.1.1(2). Galvanized steel shall conform to ASTM A 653. Metallic ducts shall be fabricated in accordance with SMACNA Duct Construction Standards Metal and Flexible.

5. Use of gypsum products to construct return air ducts or plenums is permitted, provided that the air temperature does not exceed $125^{\circ} \mathrm{F}\left(52^{\circ} \mathrm{C}\right)$ and exposed surfaces are not subject to condensation.

6. Duct systems shall be constructed of materials having a flame spread index not greater than 200.

7. Stud wall cavities and the spaces between solid floor joists to be used as air plenums shall comply with the following conditions:

7.1. These cavities or spaces shall not be used as a plenum for supply air.

7.2. These cavities or spaces shall not be part of a required fire-resistance-rated assembly. 
7.3. Stud wall cavities shall not convey air from more than one floor level.

7.4. Stud wall cavities and joist-space plenums shall be isolated from adjacent concealed spaces by tight-fitting fireblocking in accordance with Section R602.8.

7.5. Stud wall cavities in the outside walls of building envelope assemblies shall not be utilized as air plenums.

M1601.1.2 Underground duct systems. Underground duct systems shall be constructed of approved concrete, clay, metal or plastic. The maximum duct temperature for plastic ducts shall not be greater than $150^{\circ} \mathrm{F}\left(66^{\circ} \mathrm{C}\right)$. Metal ducts shall be protected from corrosion in an approved manner or shall be completely encased in concrete not less than 2 inches $(51 \mathrm{~mm})$ thick. Nonmetallic ducts shall be installed in accordance with the manufacturer's installation instructions. Plastic pipe and fitting materials shall conform to cell classification 12454-B of ASTM D 1248 or ASTM D 1784 and external loading properties of ASTM D 2412. All ducts shall slope to an accessible point for drainage. Where encased in concrete, ducts shall be sealed and secured prior to any concrete being poured. Metallic ducts having an approved protective coating and nonmetallic ducts shall be installed in accordance with the manufacturer's installation instructions.

M1601.2 Factory-made ducts. Factory-made air ducts or duct material shall be approved for the use intended and shall be installed in accordance with the manufacturer's installation instructions. Each portion of a factory-made air duct system shall bear a listing and label indicating compliance with UL 181 and UL 181A or UL $181 \mathrm{~B}$.

M1601.3 Duct insulation materials. Duct insulation materials shall conform to the following requirements:

1. Duct coverings and linings, including adhesives where used, shall have a flame spread index not higher than 25, and a smoke-developed index not over 50 when tested in accordance with ASTM E 84 or UL 723, using the specimen preparation and mounting procedures of ASTM E 2231.

2. Duct coverings and linings shall not flame, glow, smolder or smoke when tested in accordance with ASTM C 411 at the temperature to which they are exposed in service. The test temperature shall not fall below $250^{\circ} \mathrm{F}\left(121^{\circ} \mathrm{C}\right)$. Coverings and linings shall be listed and labeled.

M1601.4 Installation. Duct installation shall comply with Sections M1601.4.1 through M1601.4.7.

M1601.4.6 Factory-made air ducts. Factory-made air ducts shall not be installed in or on the ground, in tile or metal pipe, or within masonry or concrete. 
Table 1. Summary of Key Code Issues Related to Duct System Flammability and Smoke Developed

M1601.1.1 2. Factory-made air ducts shall be constructed of Class 0 or Class 1 materials as designated in Table M1601.1.1(1).

TABLE M1601.1.1(1)

CLASSIFICATION OF FACTORY-MADE AIR DUCTS

\begin{tabular}{cc}
\hline DUCT & $\begin{array}{c}\text { MAXIMUM FLAME } \\
\text { CLASS }\end{array}$ \\
\hline $\mathbf{0}$ & 0 \\
$\mathbf{1}$ & 25
\end{tabular}

6. Duct systems shall be constructed of materials having a flame spread index not greater than 200 .

M1601.1.2 Underground duct systems shall be constructed of approved concrete, clay, metal or plastic.

M1601.2 Factory-made air ducts or duct material shall be approved for the use intended...

Each portion of a factory-made air duct system shall bear a listing and label indicating compliance with UL 181 and UL 181A or UL 181B.

M1601.3 1. Duct coverings and linings, including adhesives where used, shall have a flame spread index not higher than 25 , and a smoke-developed index not over $50 \ldots$

2. Duct coverings and linings shall not flame, glow, smolder or smoke when tested in accordance with ASTM C $411 \ldots$

M1601.4.6 Factory-made air ducts shall not be installed in or on the ground, in tile or metal pipe, or within masonry or concrete.

\subsection{Other Citations}

\subsubsection{UL 181 Factory-Made Air Ducts and Air Connectors [UL 181 (2013)]}

1. Scope

1.1 These requirements apply to materials for the fabrication of air duct and air connector systems for use in accordance with the International Mechanical Code (IMC), International Residential Code (IRC), and Uniform Mechanical Code (UMC), Standards of the National Fire Protection Association for the Installation of Air-Conditioning and Ventilating Systems, NFPA 
No. 90A, and the Installation of Warm Air Heating and Air-Conditioning Systems, NFPA No. 90B.

1.2 The air ducts and air connectors covered by these requirements include preformed lengths of flexible or rigid ducts, materials in the form of boards for field fabrication of lengths of rigid ducts, and preformed flexible air connectors.

1.3 For the purpose of these requirements, air ducts and air connectors are classified as follows:

Class 0 - Air ducts and air connectors having surface burning characteristics of zero.

Class 1 - Air ducts and air connectors having a flame-spread index of not over 25 without evidence of continued progressive combustion and a smoke-developed index of not over 50 .

\subsection{Images}

Not applicable.

\subsection{Discussion of Conflict and Underlying Building Performance Criteria}

One way to look at the purpose of a building code is to describe a hierarchy of intent. One such hierarchy could be as follows:

1. Limit the flammability of the building through minimum materials and systems requirements (e.g., flame spread).

2. Get the occupants safely out of the building in the event of a fire.

3. Protect the safety of firefighters and emergency responders.

4. Protect structures adjacent to the property where the fire is located.

5. Minimize the damage to the structure that is on fire.

\subsubsection{Building Flammability and Safety for Occupants in the Event of a Fire}

Current building codes have evolved to balance the flammability of materials that go into a building; different buildings are recognized to have different fire hazards and life safety requirements. A densely populated high-rise office building will have different structure and finish requirements for fire safety than those of an accessory building with no permanent human occupants. That being said, the IRC has many requirements for materials, specifically with respect to flame spread and smoke-developed indices. For example, IRC Section R302.9 allows a flame spread index and smoke-developed index of 200/450 for wall and ceiling finishes, and IRC Section R302.10.1 allows 25/450 for insulation materials and exposed facings, such as vapor retarders and vapor-permeable membranes, installed within floor/ceiling assemblies, roof/ceiling assemblies, wall assemblies, crawlspaces, and attics. IRC Section R316.5.9 allows up to 10\% of the interior surface area of the house to be finished with foam plastic interior trim, with a flame spread not greater than 75 and an unlimited smoke-developed index. These limits are significantly higher than those for factory-made air ducts. States and local municipalities also may impose flammability standards for the possessions that people bring into a home that are outside the scope of the building code. 
Duct flame spread and smoke-developed ratings are likely due to fires in duct systems in the early 1900s (National Board of Fire Underwriters [NBFU], NBFU 1935, p. 12). A primary concern was that the interior lining of ducts caught fire and proved difficult for firefighters to access and extinguish.

Another concern was the amount of smoke generated and distributed through the buildings by the central air handlers. NBFU (1915) provides guidance in the form of code language that ducts be "made of galvanized iron or other approved non combustible material" and recommended that fans be interconnected to fire and smoke alarm systems so the fans shut down in the event of a fire. NBFU (1935) also indicates that "only fire resistive linings acceptable to the inspection department having jurisdiction may be used inside of ducts." Smoke and gases from the insides of duct systems may limit the ability of the occupants to evacuate the building in a timely fashion, especially if the smoke and gases are distributed actively by the central air handler.

In the event of a fire, the first task is to alert occupants about the fire so they can exit the building safely. Then the fire needs to be suppressed to prevent it from spreading and to minimize damage to the building that is on fire and to possible adjacent structures. To address these issues, the 2012 IRC requires the installation of smoke alarms (IRC Section R314) and automatic fire sprinkler systems (IRC Section R313) (IRC 2012).

\subsubsection{Building Safety for Firefighters and Emergency Responders}

A central air handling fan can effectively distribute smoke and hot gases throughout a building, which can limit visibility for firefighters. The 2012 IRC does not require the automatic disconnect of power to an air handler fan when the smoke alarm system detects a fire. Depending on where the fire is located with respect to the return air intake for the duct system, smoke and hot gases may be effectively distributed throughout the house during a fire, regardless of the flame spread or smoke-developed rating of the duct system.

Minimum equipment safety standards have moved manufacturers to include a high temperature limit shutoff switch within furnaces and heat pumps, but generally these control only the source of heat within the equipment (e.g., gas valve or compressor); the fan continues operating to help cool the heat exchanger. Therefore, internal high limit switches in furnaces and heat pumps do not necessarily mitigate the movement of smoke and hot gases by the air handler fan via the duct system.

Because duct systems inherently connect various rooms in a house, another concern is the transfer of fire from one room to another via the inside of the duct. If the air handler fan is inactive, fire on the inside of a duct can spread against the normal path of airflow. It is not known if a fire spreads faster via a duct system or room to room via the allowable flame spread of materials cited in the 2012 IRC Sections R302.9, R302.10.1, and R316.5.9 (IRC 2012). Firefighters cannot know the routing of the duct system, and if fire is spreading in the system, they may not be able to anticipate where it will manifest itself next. Duct systems also are typically routed through cavities behind the drywall of the house; as such, if the fire burns through the duct system, the house structure may be exposed more quickly to the fire. 


\subsection{Strategies to Discuss with Code Officials to Meet the Intent of the International Residential Code}

Different parts of IRC Sections M1601.1 and M1601.2 are contradictory and do not appear to follow any common logic (IRC 2012). IRC Section M1601.1.1(6) specifically enables the use of duct systems that have a flame spread not greater than 200. IRC Section M1601.1.2 explicitly allows plastic ducts underground, provided the supply air temperature is lower than $150^{\circ} \mathrm{F}$. Unfortunately, IRC Sections M1601.1.1(2), M1601.2, and M1602.3 contradict sections M1601.1.1(6) and M1601.1.2, in that factory-made ducts and insulating linings are required to meet UL 181 having a flame spread of not greater than 25 and a smoke-developed index of not more than 50 .

\subsubsection{Possible Approach}

1. Work with the building official on a hierarchy of safety concerns that the building code seeks to achieve, through which to evaluate the use of alternative duct materials. One hierarchy of safety would be as follows:

a. Limit the flammability of the building.

b. Get the occupants safely out of the building in the event of a fire.

c. Ensure the safety of firefighters and emergency responders.

d. Protect structures adjacent to the property where the fire is located.

e. Minimize damage to the structure that is on fire.

2. Identify fire safety components of the code that help mitigate these safety concerns for the above hierarchy of safety. For example:

a. Limit the flammability of the building through minimum materials and systems requirements (e.g., flame spread).

(1) Ensure that the building meets all other fire and materials requirements of the code.

(2) There is little evidence that new central space conditioning equipment or duct systems pose a significant fire safety risk:

i. Ahrens (2013) states in Table 5 that "heating equipment" was the leading cause of $16 \%$ of home structure fires in 2007 to 2011 . Table 7 in Ahrens (2013) further states that only 4\% of fires in this period were caused by "Furnace, central heat or boiler."

ii. Table 3.E in Hall (2013) shows space heating devices have an 8 times higher risk of fire (per million user households) than central heating and cause 62 times the number of civilian deaths per million user households.

iii. Table 3.3A in Hall (2013) shows 2\% (200 total) of the annual average "item first ignited" in home central heating unit fires was "duct, pipe, conduit or hose." Furthermore, 1\% (100 total) of the annual average "item first ignited" in home central heating unit fires was "duct, pipe, conduit or hose covering." These combined 
“items first ignited" (300 total) resulted in no civilian deaths and only seven civilian injuries.

iv. These statistics indicate that, compared to the 366,600 total average number of home fires between 2007 and 2011 (Ahrens 2013), the 300 total involving duct systems (Hall 2013) is very low, and civilian deaths are nonexistent. As such, there appears to be a relatively low risk associated with alternative duct materials that comply with 2012 IRC Section M1601.1.1(6) and 2012 IRC Section M1601.1.2.

Note that Ahrens (2013) and Hall (2013) do not provide any data about the age of the homes or the life safety code under which the homes were built as a factor against which the statistics presented can be cross correlated.

b. Get the occupants safely out of the building in the event of a fire.

(1) A smoke/carbon monoxide alarm system alerts the occupants (IRC Sections R314 and R315).

(2) The house is built to current code life and fire safety requirements providing multiple egress options for occupants (e.g., IRC Section R302, Chapter 3, windows in bedrooms, hallways, stairs, and exterior doors).

(3) The building has a fire suppression system (IRC Section R313).

3. Ensure the safety of firefighters and emergency responders.

a. The structure of the building meets current code life and fire safety requirements (e.g., IRC Chapter 3, windows in bedrooms, hallways, stairs, and exterior doors; fireblocking; and draftstopping).

b. The building has a fire suppression system (IRC Section R313).

4. Protect structures adjacent to the property that is on fire.

a. The structure of the building meets current code life and fire safety requirements (e.g., IRC Chapter 3).

5. Minimize damage to the structure that is on fire.

a. Local planning and zoning ordinances allow firefighters and first responders access to the building on fire.

Given this set of concerns, there appears to be little safety impact by approving a duct system that meets 2012 IRC Sections M1601.1.1(6) and M1601.1.2 but does not meet Sections M1601.1.1(2) and M1601.2, especially because other components of the duct system (e.g., registers, dampers) can have a flame spread no greater than 200, according to 2012 IRC M1601.1.1(6). 


\section{Completed Template-Air Sealing of Fire Separation Assemblies}

IBACOS has completed the following template for the air sealing of fire separation assemblies in one- and two-family buildings.

\subsection{Air Sealing of Fire Separation Assemblies-Summary}

In the 2012 IRC (IRC 2012) and the 2012 IECC (IECC 2012), one- and two-family houses must prescriptively be shown to be less than either $5 \mathrm{ACH} @ 50 \mathrm{~Pa}$ or $3 \mathrm{ACH} @ 0$ Pa, based on climate zone. In attached housing, the fire separation assembly between units can be a source of air leakage; however, current ASTM E119 - 12a (2012) tests of these fire separation assemblies have not included any materials that substantially air seal the gap at the perimeter of the wall system where it intersects the thermal envelope.

\subsection{Relevant Code Sections}

\subsubsection{International Residential Code}

Code citations in this subsection are taken directly from the 2012 IRC (IRC 2012), reproduced here with permission from the ICC as detailed in the Acknowledgments section of this report. (All rights reserved. www.ICCSAFE.org.) Relevant sections are highlighted in yellow. Table 2 follows the code citations and lists a summary of specific code issues.

Note that although Table N1102.4.1.1 (IECC Section R402.1.1 [IECC 2012]) implies that all gaps and cracks in the building envelope air barrier should be sealed, no specific provisions for air sealing vertical or horizontal fire separation assemblies are included. The code is silent relative to the interpretation of when a fire separation assembly is part of the building thermal envelope and therefore part of the building air barrier. It is also implied, but not specifically stated, that from a fire separation perspective, air sealing assemblies help to limit the passage of hot smoke and gases in the building (e.g., draftstopping).

\subsubsection{International Residential Code Section R302}

R302.1 Exterior walls. Construction, projections, openings and penetrations of exterior walls of dwellings and accessory buildings shall comply with Table R302.1(1); or dwellings equipped throughout with an automatic sprinkler system installed in accordance with Section P2904 shall comply with Table R302.1(2).

R302.2 Townhouses. Each townhouse shall be considered a separate building and shall be separated by fire-resistance rated wall assemblies meeting the requirements of Section R302.1 for exterior walls.

Exception: A common 1-hour fire-resistance-rated wall assembly tested in accordance with ASTM E 119 or UL 263 is permitted for townhouses if such walls do not contain plumbing or mechanical equipment, ducts or vents in the cavity of the common wall. The wall shall be rated for fire exposure from both sides and shall extend to and be tight against exterior walls and the underside of the roof sheathing. Electrical installations shall be installed in accordance with Chapters 34 through 43. Penetrations of electrical outlet boxes shall be in accordance with Section R302.4. 
R302.2.1 Continuity. The fire-resistance-rated wall or assembly separating townhouses shall be continuous from the foundation to the underside of the roof sheathing, deck or slab. The fireresistance rating shall extend the full length of the wall or assembly, including wall extensions through and separating attached enclosed accessory structures.

R302.2.4 Structural independence. Each individual townhouse shall be structurally independent.

Exceptions:

1. Foundations supporting exterior walls or common walls.

2. Structural roof and wall sheathing from each unit may fasten to the common wall framing.

3. Nonstructural wall and roof coverings.

4. Flashing at termination of roof covering over common wall.

5. Townhouses separated by a common 1-hour fire resistance-rated wall as provided in Section R302.2.

R302.4 Dwelling unit rated penetrations. Penetrations of wall or floor/ceiling assemblies required to be fire-resistance rated in accordance with Section R302.2 or R302.3 shall be protected in accordance with this section.

R302.4.1 Through penetrations. Through penetrations of fire-resistance-rated wall or floor assemblies shall comply with Section R302.4.1.1 or R302.4.1.2.

Exception: Where the penetrating items are steel, ferrous or copper pipes, tubes or conduits, the annular space shall be protected as follows:

1. In concrete or masonry wall or floor assemblies, concrete, grout or mortar shall be permitted where installed to the full thickness of the wall or floor assembly or the thickness required to maintain the fire-resistance rating, provided:

1.1. The nominal diameter of the penetrating item is a maximum of 6 inches $(152 \mathrm{~mm})$; and

1.2. The area of the opening through the wall does not exceed 144 square inches $\left(92,900 \mathrm{~mm}^{2}\right)$.

2. The material used to fill the annular space shall prevent the passage of flame and hot gases sufficient to ignite cotton waste where subjected to ASTM E 119 or UL 263 time temperature fire conditions under a minimum positive pressure differential of 0.01 inch of water $(3 \mathrm{~Pa})$ at the location of the penetration for the time period equivalent to the fire-resistance rating of the construction penetrated.

R302.4.1.1 Fire-resistance-rated assembly. Penetrations shall be installed as tested in the approved fire-resistance-rated assembly. 
R302.4.1.2 Penetration firestop system. Penetrations shall be protected by an approved penetration firestop system installed as tested in accordance with ASTM E 814 or UL 1479, with a minimum positive pressure differential of 0.01 inch of water $(3 \mathrm{~Pa})$ and shall have an $\mathrm{F}$ rating of not less than the required fire-resistance rating of the wall or floor/ceiling assembly penetrated.

R302.4.2 Membrane penetrations. Membrane penetrations shall comply with Section R302.4.1. Where walls are required to have a fire-resistance rating, recessed fixtures shall be installed so that the required fire-resistance rating will not be reduced.

\section{Exceptions:}

1. Membrane penetrations of maximum 2-hour fire-resistance-rated walls and partitions by steel electrical boxes that do not exceed 16 square inches $\left(0.0103 \mathrm{~m}^{2}\right)$ in area provided the aggregate area of the openings through the membrane does not exceed 100 square inches $\left(0.0645 \mathrm{~m}^{2}\right)$ in any 100 square feet $(9.29 \mathrm{~m})^{2}$ of wall area. The annular space between the wall membrane and the box shall not exceed 1/8 inch $(3.1 \mathrm{~mm})$. Such boxes on opposite sides of the wall shall be separated by one of the following:

1.1. By a horizontal distance of not less than 24 inches $(610 \mathrm{~mm})$ where the wall or partition is constructed with individual noncommunicating stud cavities;

1.2. By a horizontal distance of not less than the depth of the wall cavity when the wall cavity is filled with cellulose loose-fill, rockwool or slag mineral wool insulation;

1.3. By solid fireblocking in accordance with Section R302.11;

1.4. By protecting both boxes with listed putty pads; or

1.5. By other listed materials and methods.

2. Membrane penetrations by listed electrical boxes of any materials provided the boxes have been tested for use in fire-resistance-rated assemblies and are installed in accordance with the instructions included in the listing. The annular space between the wall membrane and the box shall not exceed 1/8 inch $(3.1 \mathrm{~mm})$ unless listed otherwise. Such boxes on opposite sides of the wall shall be separated by one of the following:

2.1. By the horizontal distance specified in the listing of the electrical boxes;

2.2. By solid fireblocking in accordance with Section R302.11;

2.3. By protecting both boxes with listed putty pads; or

2.4. By other listed materials and methods.

3. The annular space created by the penetration of a fire sprinkler provided it is covered by a metal escutcheon plate. 
R302.11 Fireblocking. In combustible construction, fireblocking shall be provided to cut off all concealed draft openings (both vertical and horizontal) and to form an effective fire barrier between stories, and between a top story and the roof space. Fireblocking shall be provided in wood-frame construction in the following locations:

1. In concealed spaces of stud walls and partitions, including furred spaces and parallel rows of studs or staggered studs, as follows:

\subsection{Vertically at the ceiling and floor levels.}

1.2. Horizontally at intervals not exceeding 10 feet $(3048 \mathrm{~mm})$.

2. At all interconnections between concealed vertical and horizontal spaces such as occur at soffits, drop ceilings and cove ceilings.

3. In concealed spaces between stair stringers at the top and bottom of the run. Enclosed spaces under stairs shall comply with Section R302.7.

4. At openings around vents, pipes, ducts, cables and wires at ceiling and floor level, with an approved material to resist the free passage of flame and products of combustion. The material filling this annular space shall not be required to meet the ASTM E 136 requirements.

5. For the fireblocking of chimneys and fireplaces, see Section R1003.19.

6. Fireblocking of cornices of a two-family dwelling is required at the line of dwelling unit separation.

R302.11.1 Fireblocking materials. Except as provided in Section R302.11, Item 4, fireblocking shall consist of the following materials.

1. Two-inch (51 mm) nominal lumber.

2. Two thicknesses of 1-inch $(25.4 \mathrm{~mm})$ nominal lumber with broken lap joints.

3. One thickness of 23/32-inch $(18.3 \mathrm{~mm})$ wood structural panels with joints backed by $23 / 32$ inch $(18.3 \mathrm{~mm})$ wood structural panels.

4. One thickness of 3/4-inch $(19.1 \mathrm{~mm})$ particleboard with joints backed by 3/4-inch $(19.1 \mathrm{~mm})$ particleboard.

5. One-half-inch (12.7 mm) gypsum board.

6. One-quarter-inch $(6.4 \mathrm{~mm})$ cement-based millboard.

7. Batts or blankets of mineral wool or glass fiber or other approved materials installed in such a manner as to be securely retained in place.

8. Cellulose insulation installed as tested for the specific application. 
R302.11.1.1 Batts or blankets of mineral or glass fiber. Batts or blankets of mineral or glass fiber or other approved nonrigid materials shall be permitted for compliance with the 10-foot (3048 mm) horizontal fireblocking in walls constructed using parallel rows of studs or staggered studs.

R302.11.1.2 Unfaced fiberglass. Unfaced fiberglass batt insulation used as fireblocking shall fill the entire cross section of the wall cavity to a minimum height of 16 inches $(406 \mathrm{~mm})$ measured vertically. When piping, conduit or similar obstructions are encountered, the insulation shall be packed tightly around the obstruction.

R302.11.1.3 Loose-fill insulation material. Loose-fill insulation material shall not be used as a fireblock unless specifically tested in the form and manner intended for use to demonstrate its ability to remain in place and to retard the spread of fire and hot gases.

R302.11.2 Fireblocking integrity. The integrity of all fireblocks shall be maintained.

\subsubsection{International Residential Code Section N1102.4}

N1102.4 (R402.4) Air leakage (Mandatory). The building thermal envelope shall be constructed to limit air leakage in accordance with the requirements of Sections N1102.4.1 through N1102.4.4.

N1102.4.1 (R402.4.1) Building thermal envelope. The building thermal envelope shall comply with Sections N1102.4.1.1 and N1102.4.1.2. The sealing methods between dissimilar materials shall allow for differential expansion and contraction.

N1102.4.1.1 (R402.4.1.1) Installation. The components of the building thermal envelope as listed in Table N1102.4.1.1 shall be installed in accordance with the manufacturer's instructions and the criteria listed in Table N1102.4.1.1, as applicable to the method of construction. Where required by the building official, an approved third party shall inspect all components and verify compliance.

N1102.4.1.2 (R402.4.1.2) Testing. The building or dwelling unit shall be tested and verified as having an air leakage rate of not exceeding 5 air changes per hour in Zones 1 and 2, and 3 air changes per hour in Zones 3 through 8 . Testing shall be conducted with a blower door at a pressure of 0.2 inches w.g. (50 Pascals). Where required by the building official, testing shall be conducted by an approved third party. A written report of the results of the test shall be signed by the party conducting the test and provided to the building official. Testing shall be performed at any time after creation of all penetrations of the building thermal envelope.

\subsubsection{International Energy Conservation Code}

Code citations in this subsection are taken directly from the 2012 IECC, reproduced here with permission from the ICC as detailed in the Acknowledgments section of this report. (All rights reserved. www.ICCSAFE.org.) Relevant sections are highlighted in yellow. Again, Table 2 follows the code citations and lists a summary of specific code issues.

\subsubsection{International Energy Conservation Code Section R402.4}

R402.4 Air leakage (Mandatory). The building thermal envelope shall be constructed to limit air leakage in accordance with the requirements of Sections R402.4.1 through R402.4.4. 
R402.4.1 Building thermal envelope. The building thermal envelope shall comply with Sections R402.4.1.1 and R402.4.1.2. The sealing methods between dissimilar materials shall allow for differential expansion and contraction.

R402.4.1.1 Installation. The components of the building thermal envelope as listed in Table R402.4.1.1 shall be installed in accordance with the manufacturer's instructions and the criteria listed in Table R402.4.1.1, as applicable to the method of construction. Where required by the code official, an approved third party shall inspect all components and verify compliance.

R402.4.1.2 Testing. The building or dwelling unit shall be tested and verified as having an air leakage rate of not exceeding 5 air changes per hour in Climate Zones 1 and 2, and 3 air changes per hour in Climate Zones 3 through 8. Testing shall be conducted with a blower door at a pressure of 0.2 inches w.g. (50 Pascals). Where required by the code official, testing shall be conducted by an approved third party. A written report of the results of the test shall be signed by the party conducting the test and provided to the code official. Testing shall be performed at any time after creation of all penetrations of the building thermal envelope.

Table 2. Fire Separation and Air Sealing Issues

\begin{tabular}{c|c}
\hline IRC R302.2 & $\begin{array}{r}\text { Townhouses. Each townhouse shall be considered a separate } \\
\text { building and shall be separated by fire-resistance rated wall } \\
\text { assemblies meeting the requirements of [IRC] Section R302.1 for } \\
\text { exterior walls. }\end{array}$ \\
IRC R302.11 & $\begin{array}{r}\text { Fireblocking. In combustible construction, fireblocking shall be } \\
\text { provided to cut off all concealed draft openings (both vertical and } \\
\text { horizontal) and to form an effective fire barrier between stories, and } \\
\text { between a top story and the roof space. }\end{array}$ \\
IRC R302.11(4) & $\begin{array}{r}\text { At openings around vents, pipes, ducts, cables and wires at ceiling } \\
\text { and floor level, with an approved material to resist the free passage } \\
\text { of flame and products of combustion. The material filling this } \\
\text { annular space shall not be required to meet the ASTM E 136 } \\
\text { requirements. }\end{array}$ \\
IRC N1102.4.1.2 & $\begin{array}{r}\text { The building or dwelling unit shall be tested and verified as having } \\
\text { an air leakage rate of not exceeding 5 air changes per hour in } \\
\text { Zones 1 and 2, and 3 air changes per hour in Zones 3 through } 8 .\end{array}$ \\
\hline
\end{tabular}

\subsection{Other Citations}

\subsubsection{ASTM E-119-12a Standard Test Methods for Fire Tests of Building Construction and Materials [ASTM E119 - 12a 2012]}

1. Scope

1.1 The test methods described in this fire-test-response standard are applicable to assemblies of masonry units and to composite assemblies of structural materials for buildings, including loadbearing and other walls and partitions, columns, girders, beams, slabs, and composite slab and beam assemblies for floors and roofs. They are also applicable to other assemblies and structural units that constitute permanent integral parts of a finished building. 


\subsubsection{ASTM E136 - 12 Standard Test Method for Behavior of Materials in a Vertical Tube Furnace at $750^{\circ} \mathrm{C}$ [ASTM E136 - 12a 2012]}

Significance and Use

While actual building fire exposure conditions are not duplicated, this test method will assist in indicating those materials which do not act to aid combustion or add appreciable heat to an ambient fire.

Materials passing the test are permitted limited flaming and other indications of combustion.

\section{Scope}

1.1 This fire-test-response test method covers the determination under specified laboratory conditions of combustion characteristics of building materials.

\subsection{Images}

Figure 1 and Figure 2 show typical shaft wall fire separation construction, with some of the typical air leakage pathways noted. Without an air sealing strategy at these gaps, it may be difficult, if not impossible, to achieve the IRC and IECC required building airtightness levels.

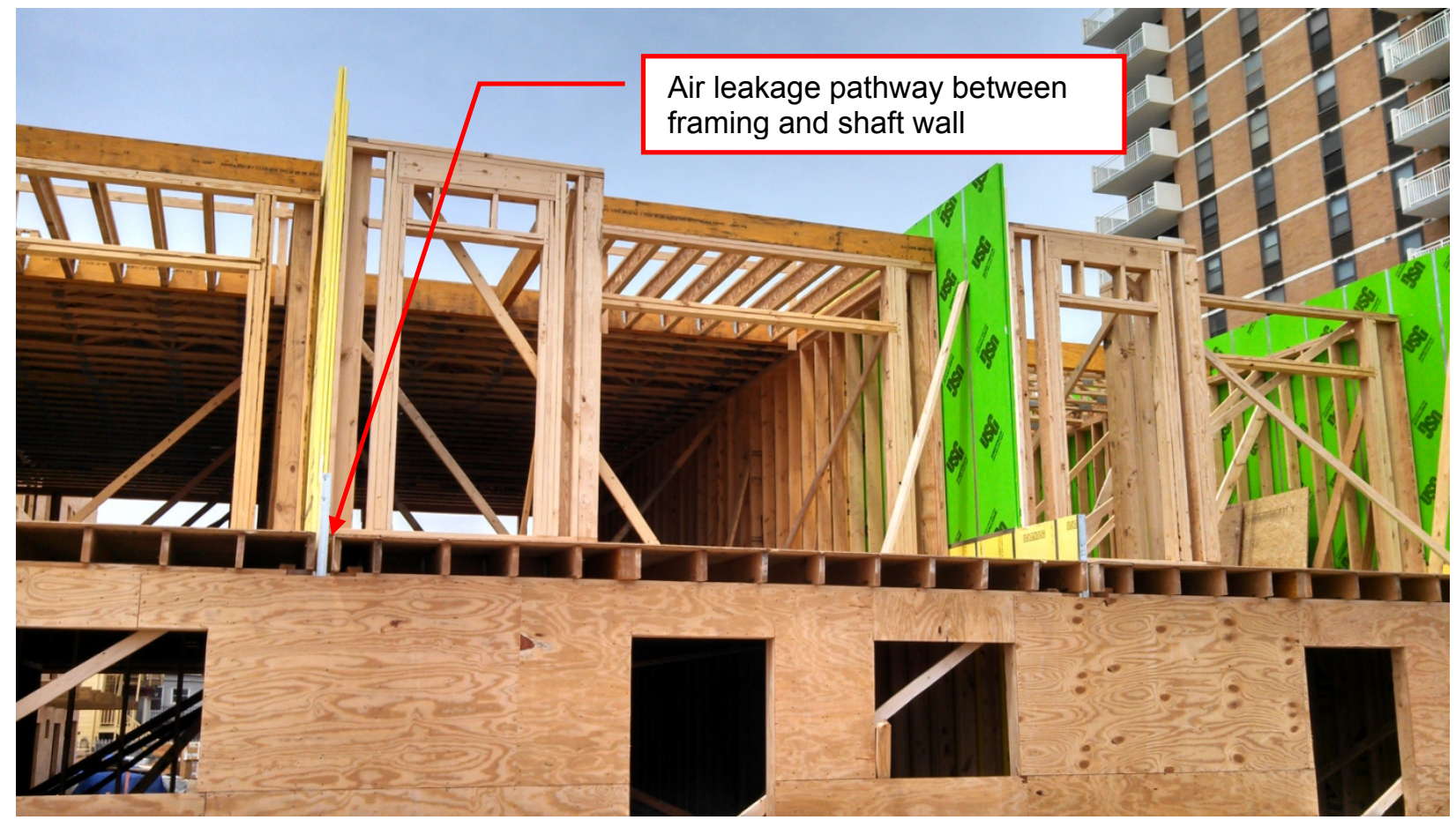

Figure 1. Fire separation walls (yellow or green gypsum shaft wall) in multifamily housing 


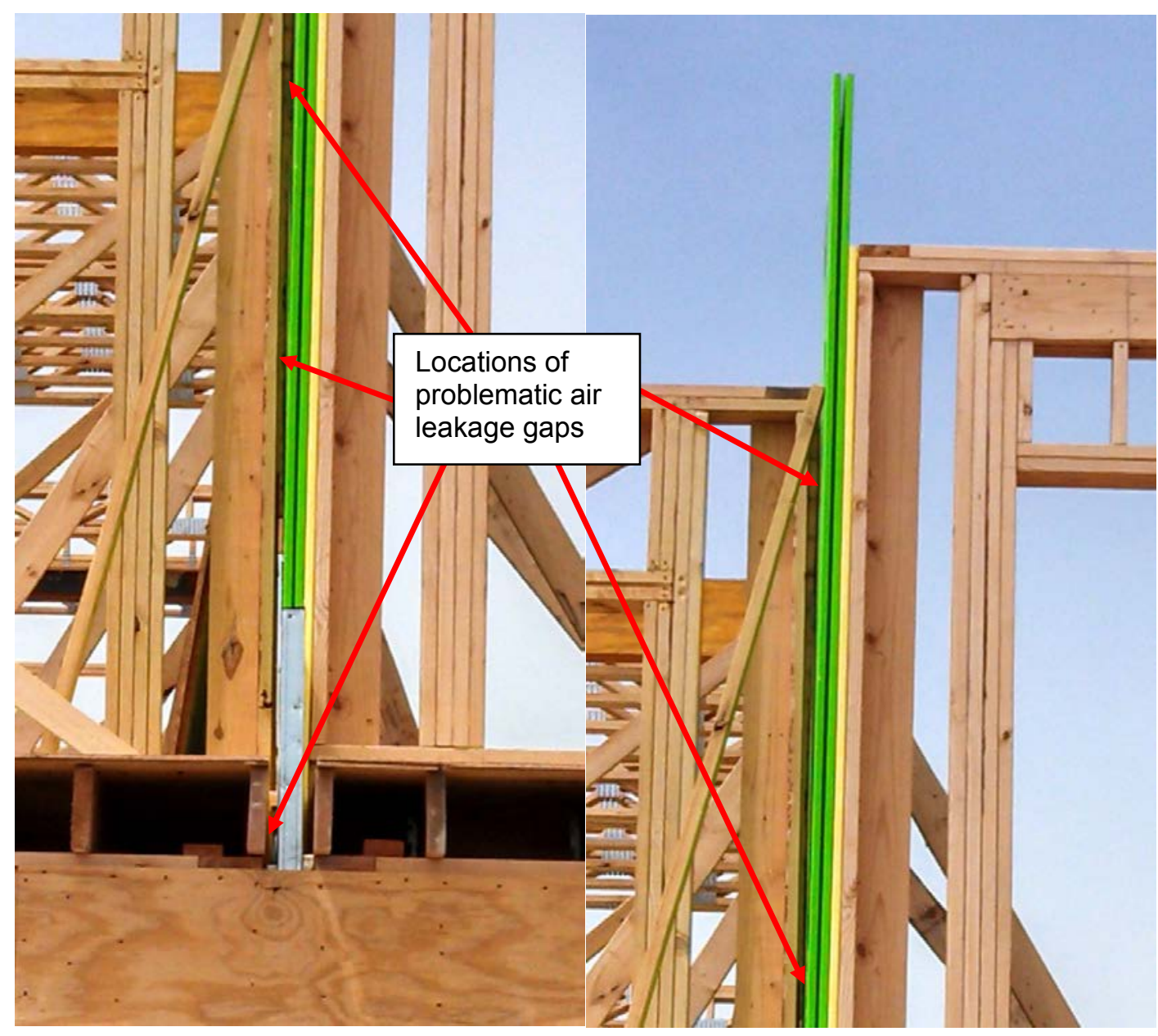

Figure 2. Examples of gaps where approved air sealing strategy is needed at the perimeter of fire separation walls

\subsection{Discussion of Conflict and Underlying Building Performance Criteria}

The UL 119 test does not include any code-prescribed fireblocking, nor does it induce any air leakage or pressure differential within the assembly. IRC Section R302.11 prescribes the location of fireblocking and the materials that are allowed but does not specifically state that other materials can be used to minimize air leakage at these locations. IRC Section R302.11(4) indicates that combustible material can be used to firestop around piping and wiring ("material filling this annular space shall not be required to meet the ASTM E 136 requirements"). It appears the underlying performance criteria are seeking to minimize the passage of air and hot gases within the assembly; however, the test for the assemblies has not included any materials to do so. Although many of the firestop materials prescribed in the code are combustible (e.g., solid wood, nominal lumber, structural sheathing material), no specific language exists to allow the use of sealants (combustible or noncombustible) in conjunction with this fireblocking.

\subsubsection{Building Safety for Occupants in the Event of a Fire}

In the event of a fire in attached townhouses, it is important to keep the fire from spreading from one unit to a neighboring attached unit. This is the purpose of the fire separation assembly (IRC Sections R302.2.1 and R302.2.4). 
It is also desirable to stop the passage of hot gases and smoke within assemblies. This is the reason for the fireblocking discussed in IRC Section R302.11. Fireblocking can be combustible material (IRC R302.11.1) and needs to be located at prescribed locations in the building.

\subsubsection{Building Safety for Firefighters and Emergency Responders}

If one unit of a townhouse building that is engulfed in a fire collapses, it is desirable for the remainder of the building to remain standing. Fire separation assemblies are thus designed to maintain structural independence from one unit to the next, with limited connections allowed at wall and roof sheathing (IRC Sections R302.2.1 and R302.2.4).

Fireblocking as described in IRC Section R302.11 is desirable from a firefighter's perspective, in that it limits the movement of fire in concealed cavities in the building, such as those found within fire separation assemblies.

\subsection{Strategies to Discuss with Code Officials to Meet the Intent of the International Residential Code}

The intents of the code in townhouse construction are to prevent fire from transferring from one unit to another, to minimize the movement of fire in concealed spaces, and to allow for the collapse of one unit without compromising the structural integrity of adjacent units.

Fireblocking is specifically required; however, the code is not specific relative to the use of fireblocking inside ASTM E119 - 12a (2012) or UL 263 (2011) tested assemblies or where these assemblies start and stop with respect to the air control layer needed to meet the air leakage requirements in IRC Section R402.4.1.2. The UL BXUV.GuideInfo Fire-resistance Ratings ANSI/UL $263^{3}$ (UL BXUV 2013) states:

Walls of combustible construction should be fireblocked between floors, between the top story and the roof or attic, and at certain intervals laterally in accordance with the provisions of the applicable code to prevent the free passage of flames and hot gases.

This implies that fireblocking materials as listed in IRC Section 302.11 would be acceptable within the assembly, including material stated in IRC Section R302.11(4):

At openings around vents, pipes, ducts, cables and wires at ceiling and floor level, with an approved material to resist the free passage of flame and products of combustion. The material filling this annular space shall not be required to meet the ASTM E 136 requirements.

A material that meets the ASTM E136-12 requirements (ASTM E136 - 12 2012) will not support combustion when subjected to a $750^{\circ} \mathrm{F}$ vertical tube furnace for 30 minutes. Many of the materials listed in IRC Section R304.11 do not meet ASTM E136-12 requirements, and the code official must decide whether or not to approve the use of materials in these assemblies. A strong argument can be made that the use of a limited amount of sealant that does not meet ASTM E136-12 at the perimeter of the building enclosure for air sealing purposes is a form of fireblocking and is allowed under IRC Section R302.11.

\footnotetext{
${ }^{3}$ http://database.ul.com/cgi-bin/XYV/template/LISEXT/1FRAME/showpage.html?name=BXUV.GuideInfo\&ccnshorttitle=Fire-

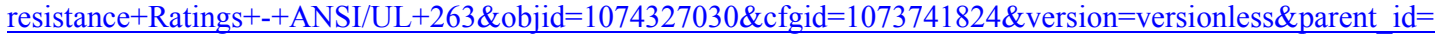
$1073984818 \&$ sequence $=1$
} 


\section{References}

Ahrens, M. (2013). Home Structure Fires. Quincy, MA: National Fire Protection Association. Accessed June 15, 2014:

www.nfpa.org/ /media/files/research/nfpa\%20reports/occupancies/oshomes.pdf.

ASTM E119 - 12a (2012). Standard Test Methods for Fire Tests of Building Construction and Materials. West Conshohocken, PA: ASTM International.

ASTM E136 - 12 (2012). Standard Test Method for Behavior of Materials in a Vertical Tube Furnace at $750^{\circ} \mathrm{C}$. West Conshohocken, PA: ASTM International.

Bohac, D., M.J. Hewett, S.K. Hammond, and D.T. Grinsrud (2011). Secondhand Smoke Transfer and Reductions by Air Sealing and Ventilation in Multiunit Buildings: PFT and Nicotine Verification. Minneapolis, MN: Center for Energy and Environment. Accessed September 10, 2014: http://mncee.org/getattachment/89f8d7f6-bd21-4db4-a342-168c8eeab13f/.

Hall, J. (2013). Home Fires Involving Heating Equipment. Quincy, MA: National Fire Protection Association. Accessed June 15, 2014:

www.nfpa.org/ /media/Files/Research/NFPA\%20reports/Major\%20Causes/osheating.pdf.

IBC (2012). International Building Code. Washington, DC: International Code Council.

IECC (2012). International Energy Conservation Code. Washington, DC: International Code Council.

IMC (2012). International Mechanical Code. Washington, DC: International Code Council.

IRC (2012). International Residential Code. Washington, DC: International Code Council.

NBFU (1915). Regulations of the National Board of Fire Underwriters for the Installation of Blower Systems for Heating and Ventilating, Stock and Refuse Conveying. New York, NY: National Board of Fire Underwriters.

NBFU (1935). Ventilating and Air Conditioning Systems Employing Ducts. New York, NY: National Board of Fire Underwriters.

UL 181 (2013). Factory-Made Air Ducts and Air Connectors, UL 181. Northbrook, IL: Underwriters Laboratories, Inc. Accessed June 15, 2014:

www.ul.com/global/eng/pages/solutions/standards/accessstandards/catalogofstandards/standard/? $\underline{\mathrm{id}=181 \quad 11 \& \text { docType }=\text { ulstd }}$

UL 263 (2011). Standard for Fire Tests of Building Construction and Materials, UL 263.

Northbrook, IL: Underwriters Laboratories, Inc. Accessed June 15, 2014 :

www.ul.com/global/eng/pages/solutions/standards/accessstandards/catalogofstandards/standard/? $\underline{\mathrm{id}=263 \quad 14 \& \text { doc Type }=\text { ulstd. }}$.

UL BXUV (2013). UL BXUV.GuideInfo Fire-resistance Ratings - ANSI / UL 263. Northbrook, IL: Underwriters Laboratories, Inc. Accessed June 15, 2014: http://database.ul.com/cgibin/XYV/template/LISEXT/1FRAME/showpage.html?name=BXUV.GuideInfo\&ccnshorttitle= Fire-resistance + Ratings+-+ANSI/UL+263\&objid=1074327030\&cfgid=1073741824\&version= versionless\&parent_id=1073984818\&sequence $=1$. 
